\title{
PROSES SENGKETA ANTROPOLIOGI HUKUM DAN PERKEMBANGANNYA
}

\author{
Alhabsi Dasriza \\ Email : alhabsidasriza0101@gmail.com \\ No. BP : 2110003600272 \\ Universitas Ekasakti Padang
}

\section{A. PENDAHULUAN}

Sengketa dapat terjadi pada siapa saja dan dimana saja. Sengketa dapat terjadi antara individu dengan individu, antara individu dengan kelompok, antara kelompok dengan kelompok, antara perusahaan dengan perusahaan, antara perusahaan dengan negara, antara negara satu dengan yang lainnya, dan sebagainya. Dengan kata lain, sengketa dapat bersifat publik maupun bersifat keperdataan dan dapat terjadi baik dalam lingkup lokal, nasional maupun internasional. Menurut Nurnaningsih Amriani (2012), yang dimaksud dengan sengketa adalah perselisihan yang terjadi antara pihak-pihak dalam perjanjian karena adanya won prestasi yang dilakukan oleh salah satu pihak dalam perjanjian.

Menganalisis siapa dan mengapa mereka terlibat adalah salah satu aspek yang penting dalam studi tentang sengketa. Untuk itu perlu dipahami dengan baik siapa subjek yang terlibat dalam sengketa tersebut dan apa objek yang dilibatkan. Subjek didefinisikan sebagai para pelaku yang terlibat dalam sengketa, baik pelaku yang mempengaruhi ataupun yang dipengaruhi. Hal ini dapat bersifat individu, masyarakat, kelompok sosial atau institusi. Objek sengketa selalu berkembang. Jika dimasa lalu objek sengketa merupakan sesuatu yang sangat konkrit dan kasat mata, maka saat ini makin banyak objek sengketa yang abstrak dan terlihat langsung. Kalau dulu contoh sengketa seperti perebutan lahan, sekarang sudah masuk ke dalam perebutan uadra bersih, keanekaragaman hayati, dan berbagai hal lain yang belum diketahui fungsi dan kegunaannya.

Ilmu hukum merupakan ilmu yang sifatnya universal. Antropologi menelaah hukum bertolak dari kenyataan dengan pendekatan empiris. Dalam pengamatan-pengamatan empiris kelihatan bahwa hukum yang dirumuskan secara universal, artinya berlaku umum untuk suatu wilayah tertentu. Sebagai ilmu perilaku/empiris, antropologi hukum lebih menitik beratkan pada kenyataan-kenyataan hukum yang nampak dalam situasi atau peristiwa hukum (law in action) tidak hukum dalam dalam peraturan perundangan tertulis (law in book). Dalam arti lain, antropologi hukum mempunyai konsekuensi bahwa teorinya hrus didukung oleh fakta yang relevan atau setidaknya terwakili secara representatif.

Antropologi hukum pada dasarnya mempelajari hubungan timbal balik antara hukum dengan fenomena - fenomena sosial secara empiris dalam kehidupan masyarakat, bagaimana 
hukum berfungsi dalam kehidupan masyarakat, atau bagaimana hukum bekerja sebagai alat pengendali sosial (social control) atau sarana untuk menjaga keteraturan sosial (social order) dalam masyarakat. Soerjono Soekanto (1982) berpendapat bahwa semua masyarakat mempunyai aturan-aturan yang mengatur perilaku manusia. Aturan - aturan tertentu bersifat hanya sebagai patokan preferensi, namun yang lain dianggap sebagai patokan perilaku yang pantas dilakukan. Apabila suatu aturan itu dilanggar, maka masyarakatnya lazimnya telah sepakat untuk menerapkan upaya - upaya penghukuman tertentu dan hal ini menjadi pusat perhatian para antropolog hukum.

\section{B. PEMBAHASAN}

Dalam perkembangan antropologi, masalah hukum sebenarnya juga sudah pernah ditelaah, walaupun di dalam suatu kerangka kebudayaan yang serba luas. Jika dilihat pada kata yang terbentuk, antropologi hukum memiliki 2 studi yang harus dipahami yakni ilmu antropologi dan ilmu hukum. Antropologi hukum mengkaji prilaku tentang manusia, hal ini diperkuat juga oleh Sir Henry maine yang menyatakan bahwa antropologi hukum sebagai bagian dari budaya. Pendapat lain juga mengatakan bahwa Antropologi hukum mempelajari hukum dari konteks kultur masyarakat tertentu, baik pada masyarakat modern, maupun masyarakat sederhana. Dengan kata lain, Antropologi Hukum adalah Antropologi yang mempelajari Hukum sebagai salah satu aspek dari kebudayaan.

Antropologi hukum merupakan suatu cabang spesialisasi dari antropologi budaya yang di pandang secara integrasi dalam kebudayaan, termasuk dalam kategori pengendalian sosial lainnya dari aneka jenis hukum masyarakat (Ihromi, 1989). Menurut Irianto (2009), dalam mempelajari antropologi hukum dikenal beberapa cara pendekataan atau metode yang dapat digunakan untuk melakukan studi terhadap berbagai perilaku manusia yang menyangkut hukum, yaitu pendekatan:

1. Historis, mempelajari perilaku manusia dan budaya hukumnya dengan kacamata sejarah.

2. Normatif - eksploratif, mempelajari manusia dan budaya hukumnya dengan bertitik tolak pada norma (kaidah-kaidah) hukum yang sudah ada, baik dalam bentuk kelembagaan maupun perilaku.

3. Deskriptif perilaku (Behavior), mempelajari manusia dan budaya hukumnya dengan melukiskan situasi hukum yang nyata.

4. Studi kasus, mempelajari kasus-kasus peristiwa hukum yang terjadi, terutama kasus-kasus sengketa / Trouble case method. 
Sengketa atau konflik akan selalu dijumpai dalam kehidupan manusia atau kehidupan bermasyarakat sebagai suatu suatu fenomena sosial. Tetapi di antara para ahli Antropologi Hukum terdapat kecendrungan untuk memfokuskan pada istilah "sengketa" atau "dispute" (Ihromi, 1993). Sengketa dapat didefinisikan sebagai keadaan dimana konflik tersebut dinyatakan di muka umum atau dengan melibatkan pihak ke tiga.

Takdir Rahmadi (2011) mengemukakan beberapa teori tentang sebab-sebab timbulnya sengketa, antara lain:

a. Teori hubungan masyarakat

Teori hubungan masyarakat menitik beratkan adanya ketidakpercayaan dan rivalisasi kelompok dalam masyarakat. Para penganut teori ini memberikan solusi-solusi terhadap konflik-konflik yang timbul dengan cara peningkatan komunikasi dan saling pengertian antara kelompok-kelompok yang mengalami konflik, serta pengembangan toleransi agar masyarakat lebih bisa saling menerima keberagaman dalam masyarakat.

b. Teori negosiasi

Prinsip Teori negosiasi menjelaskan bahwa konflik terjadi karena adanya perbedaan-perbedaan diantara para pihak. Para penganjur teori ini berpendapat bahwa agar sebuah konflik dapat diselesaikan, maka pelaku harus mampu memisahkan perasaan pribadinya dengan masalahmasalah dan mampu melakukan negosiasi berdasarkan kepentingan dan bukan pada posisi yang sudah tetap.

c. Teori identitas

Teori ini menjelaskan bahwa konflik terjadi karena sekelompok orang merasa identitasnya terancam oleh pihak lain. Penganut teori identitas mengusulkan penyelesaian konflik karena identitas yang terancam dilakukan melalui fasilitasi lokakarya dan dialog antara wakil-wakil kelompok yang mengalami konflik dengan tujuan mengidentifikasikan ancaman-ancaman dan kekhawatiran yang mereka rasakan serta membangun empati dan rekonsiliasi. Tujuan akhirnya adalah pencapaian kesepakatan bersama yang mengakui identitas pokok semua.

d. Teori kesalahpahaman antar budaya

Teori kesalahpahaman antar budaya menjelaskan bahwa konflik terjadi karena ketidakcocokan dalam berkomunikasi diantara orang-orang dari latar belakang budaya yang berbeda. Untuk itu, diperlukan dialog antara orang-orang yang mengalami konflik guna mengenal dan memahami budaya masyarakat lainnya, mengurangi stereotipe yang mereka miliki terhadap pihak lain. 


\section{e. Teori transformasi}

Teori ini menjelaskan bahwa konflik dapat terjadi karena adanya masalah-masalah ketidaksetaraan dan ketidakadilan serta kesenjangan yang terwujud dalam berbagai aspek kehidupan masyarakat baik sosial, ekonomi maupun politik. Penganut teori ini berpendapat bahwa penyelesaian konflik dapat dilakukan melalui beberapa upaya seperti perubahan struktur dan kerangka kerja yang menyebabkan ketidaksetaraan, peningkatan hubungan, dan sikap jangka panjang para pihak yang mengalami konflik, serta pengembangan proses-proses dan sistem untuk mewujudkan pemberdayaan, keadilan, rekonsiliasi dan pengakuan keberadaan masing-masing.

f. Teori kebutuhan atau kepentingan manusia

Pada intinya, teori ini mengungkapkan bahwa konflik dapat terjadi karena kebutuhan atau kepentingan manusia tidak dapat terpenuhi/ terhalangi atau merasa dihalangi oleh orang/ pihak lain. Kebutuhan dan kepentingan manusia dapat dibedakan menjadi tiga jenis yaitu substantif, prosedural, dan psikologis. Kepentingan substantif (substantive) berkaitan dengan kebutuhan manusia yang yang berhubungan dengan kebendaan seperti uang, sandang, pangan, papan/rumah, dan kekayaan. Kepentingan prosedural (procedural) berkaitan dengan tata dalam pergaulan masyarakat, sedangkan kepentingan psikologis (psychological) berhubungan dengan non-materiil atau bukan kebendaan seperti penghargaan dan empati.

Penyelesaian sengketa dalam beberapa literatur ditemukan beberapa cara penyelesaian sengketa yang dapat ditempuh dalam mencari keadilan. Menurut Pruitt dan Rubin (2004) terdapat lima cara penyelesaian sengketa, yaitu:

1.Contending (bertanding), yaitu mencoba menerapkan suatu solusi yang lebih disukai oleh salah satu pihak atas pihak yang lainnya.

2.Yielding (mengalah), yaitu menurunkan aspirasi sendiri dan bersedia menerima kekurangan dari yang sebetulnya diinginkan.

3. Problem solving (pemecahan masalah), yaitu mencari alternatif yang memuaskan dari kedua belah pihak.

4.Withdrawing (menarik diri), yaitu memilih meninggalkan situasi sengketa, baik secara fisik maupun psikologis.

5. Shut up (diam), yaitu tidak melakukan apa-apa.

Menurut Pahlevi (2021) dalam upaya penyelesaian sengketa terdapat 2 cara yaitu melalui litigasi dan non-litigasi. Litigasi merupakan suatu penyelesaian sengketa di ranah pengadilan yang dimana keberlakukan hukum positif di utamakan dalam penyelesaiannya. Proses litigasi semua pihak yang bersengketa saling berhadapan satu sama lain untuk 
mempertahankan hak-haknya di muka pengadilan. Hasil akhir dari suatu penyelesaian sengketa melalui litigasi adalah putusan yang menyatakan win-lose solution (Amriani, 2012). Prosedur dalam jalur litigasi ini sifatnya lebih formal dan teknis, menghasilkan kesepakatan yang bersifat menang kalah, cenderung menimbulkan masalah baru, lambat dalam penyelesaiannya, membutuhkan biaya yang mahal, tidak responsif dan menimbulkan permusuhan diantara para pihak yang bersengketa. Kondisi ini menyebabkan masyarakat mencari alternatif lain yaitu penyelesaian sengketa di luar proses peradilan formal. Penyelesaian sengketa di luar proses peradilan formal ini lah yang disebut dengan "Alternative Dispute Resolution" atau ADR (Harahap, 2008).

Sedangkan non-litigasi merupakan suatu metode penyelesaian sengketa yang dilakukan diluar pengadilan. Dalam penyelesaian sengketa melalui non-litigasi, kita telah mengenal adanya penyelesaian sengketa alternatif atau Alternative Dispute Resolution (ADR), yang dalam perspektif Undang-Undang Nomor 30 tahun 1999 tentang Arbitrase dan Alternatif Penyelesaian Sengketa, Alternative Dispute Resolution adalah suatu pranata penyelesaian sengketa di luar pengadilan berdasarkan kesepakatan para pihak dengan mengesampingkan penyelesaian sengketa secara litigasi di pengadilan. Penyelesaian secara non litigasi dapat dilakukan dengan berbagai banyak alternatif yang di tawarkan untuk mencapai suatu kesepakatan, seperti:

1. Mediasi, adalah penyelesaian sengketa alternatif yang dilakukan oleh 3 pihak yaitu antara keduabelah pihak yang bertentangan dan pihak ke-3 yang menjadi penengah nya untuk mencapai seuatu kesepakatan bersifat moderator di dalam beracaranya (mediator).

2. Arbitrasi, adalah metode penyelesaian sengketa yang dapat dilakukan oleh keduabelah pihak dengan menunjuk seorang arbiter dalam perkara yang dimana arbiter tersebut di tentukan sebelum terjadinya sengketa. Arbitrasi juga dapat dilakukan di peradilan maupun di luar peradilan. Cara penyelesaian seperti ini dapat di katakana sebagai lembaga peradilan swasta yang di Indonesia di bawah lembaga Badan Arbitrasi Nasional Indonesia (BANI).

3. Negosiasi, adalah metode penyelesaian sengketa yang diluar pengadilan dengan melakukan saling melobby keduabelah pihak yang bertentangan tanpa adanya pihak ketiga akan tetapi para pihak dilakukan dengan perwakilan masing-masing pihak.

4. Konsolidasi, adalah metode penyelesaian sengketa yang dimana kedua belah pihak di pertemukan langsung tanpa perantara dan tanpa penengah. Penyelesaian sengketa seperti ini melakukan kesepakatan dengan jalan ihtikad baik pada umumnya.

5. Advokasi, adalah metode penyelesaian sengketa yang dilakukan oleh satu pihak dalam melakukakan tuntutan terhadap pihak lawan untuk memenuhi segala tuntutan yang di inginkan. 


\section{KESIMPULAN}

Ilmu hukum merupakan ilmu yang sifatnya universal. Antropologi menelaah hukum bertolak dari kenyataan dengan pendekatan empiris. Antropologi hukum pada dasarnya mempelajari hubungan timbal balik antara hukum dengan fenomena- fenomena sosial secara empiris dalam kehidupan masyarakat. Sengketa dapat didefinisikan sebagai keadaan dimana konflik dimana didasari atas sebab dan harus ada penyelesaian secara hukum.

Takdir Rahmadi (2011) mengemukakan beberapa teori tentang sebab-sebab timbulnya sengketa, antara lain:
a. Teori hubungan masyarakat
b. Teori hubungan negosisasi
c. Teori identitas
d. Teori kesalahpahaman antar budaya
e. Teori transformasi
f. Teori Kebutuhan

Penyelesaian sengketa dalam beberapa literatur ditemukan beberapa cara penyelesaian sengketa, Menurut Pruitt dan Rubin (2004) terdapat lima cara penyelesaian sengketa, yaitu:

1.Contending (bertanding)

2.Yielding (mengalah)

3. Problem solving (pemecahan masalah)

4. Withdrawing (menarik diri)

5. Shut up (diam)

Sedangkan menurut Pahlevi (2021) dalam upaya penyelesaian sengketa terdapat 2 cara yaitu melalui litigasi dan non-litigasi. Litigasi merupakan suatu penyelesaian sengketa di ranah pengadilan yang dimana keberlakukan hukum positif di utamakan dalam penyelesaiannya. Sedangkan non-litigasi merupakan suatu metode penyelesaian sengketa yang dilakukan diluar pengadilan. 


\section{DAFTAR PUSTAKA}

Amriani, Nurnaningsih. 2011. Mediasi Altenatif Penyelesaian Sengketa Perdata di Pengadilan. Jakarta: PT. RajaGrafindo Persada

Harahap, M. Yahya 2008,Hukum Acara Perdata, Cet. 8, Sinar Grafika, Jakarta

Ihromi, T.O. 1993. Antropologi Hukum Sebuah Bunga Rampai. Jakarta: Yayasan Obor Indonesia

Irianto. 2009. Hukum Yang Bergerak Tinjauan Antropologi Hukum. Jakarta: Yayasan Obor Indonesia

Pahlevi , M.R. 2021. Penyelesaian Sengketa Tanah Garapan Melalui Non- Litigasi Pada Masyarakat Etnis Batak dan Organisasi Kepemudaan di Desa Klambir Lima Kebun. Universitas Sumatera Utara. Medan

Pruitt G, Dean dan Rubin Z Jeffrey. 2004. Teori Konflik Sosial. Jakarta: Pustaka Pelajar

Rahmadi, Takdir. 2010. Mediasi: Penye lesaian sengketa melalui pendekatan mufakat. Jakarta: PT RajaGrafindo Persada

Soerjono Soekanto, 1982, Pengantar Penelitian Hukum, Jakarta : Universitas Indonesia Press 